\title{
SOCIAL MORPHOLOGY OF POVERTY IN TOURISM AREA: A THICK DESCRIPTION STUDY IN PARAKANSALAK VILLAGE OF SUKABUMI, WEST JAVA, INDONESIA
}

\author{
Achmad RIZAL ${ }^{*}$ \\ Universitas Padjadjaran, Faculty of fisheries and Marine Science, Center for fisheries development and regional management studies, Regional Innovation \\ Program study, Postgraduate School, Jl. Raya Jatinangor Km 21, Jatinangor, Sumedang 45363, West Java, Indonesia, e-mail: achmad.rizal@unpad.ac.id
}

\section{Izza M. APRILIANI}

Universitas Padjadjaran, Faculty of fisheries and Marine Science, Center for fisheries development and regional management studies, Jl. Raya Jatinangor Km 21, Jatinangor, Sumedang 45363, West Java, Indonesia, e-mail: izza.mahdiana@unpad.ac.id

\section{Rega PERMANA}

Universitas Padjadjaran, Faculty of fisheries and Marine Science, Center for fisheries development and regional management studies, Jl. Raya Jatinangor Km 21, Jatinangor, Sumedang 45363, West Java, Indonesia, e-mail: rega.permana@unpad.ac.id

\begin{abstract}
Citation: Rizal, A., Apriliani, I.M., \& Permana, R. (2021). SOCIAL MORPHOLOGY OF POVERTY IN TOURISM AREA: A THICK DESCRIPTION STUDY IN PARAKANSALAK VILLAGE OF SUKABUMI, WEST JAVA, INDONESIA. GeoJournal of Tourism and Geosites, 34(1), 132-139. https://doi.org/10.30892/gtg.34117-628
\end{abstract}

\begin{abstract}
This research discusses ecological relations in rural areas with the people, thereby placing it within the village's poverty frame for a long time. By taking the case in Parakansalak Village, Sukabumi District, West Java, Indonesia, this research is expected to contribute to poverty studies related to natural resources and the environment. Noting the Indonesian people's great work is poverty alleviation, this research tries to provide a rationale for several villages still in the puddle. Thus, the research method used is the ethnographic method so that the strong character gets what Clifford Geertz calls thick descriptions. The results of this study reveal the facts why this is so by raising several basic things, namely: a) associated with citizens as farmers who have a level of dependence on the land that is their source of livelihood in agriculture, b) in terms of agricultural land production which is very dependent in climate, c) the level of production is not enough to provide benefits for the fulfillment of the needs of farmers because of the absence of agricultural land because the land is only limited by a handful of citizens, and d) creating a social structure that is fully agreed with the land, thus creating poverty as a form of social morphology. The impact of spatial production as a form of social morphology illustrates poverty conditions in Parakansalak Village.
\end{abstract}

Key words: poverty, farmers, social morphology, Parakansalak village

\section{INTRODUCTION}

Tourism is a sector of global economic activity used by various countries to increase their economic growth participation. Sakata and Prideaux (2012) states that tourism development and economic growth have a mutual relationship to alleviate poverty. Ashley et al. (2001) stated that tourism is an effective means of reducing poverty. Pro-Poor Tourism (PPT) has a significant effect on the opening of new job opportunities, an increase in income, the community's welfare, the growth of actors in micro-economic activities, and a reduction in the number of poor people. There is a direct relationship between economic and non-economic benefits for the poor in implementing PPT, and the positive impact of tourism on the poor (Ashley and Roe, 2002; Matarrita et al., 2010; Sakata and Prideaux, 2012; Graci, 2013; Mlambo and Ezeuduji, 2020). While Scheyvens (2009) states that tourism is not sufficiently evident in reducing poverty, it is still necessary to strengthen indicators in theory and economic concepts to show that tourism can reduce poverty. Mbaiwa (2005) even states that tourism does not contribute to poverty alleviation because of the dominance of the tourism sector by a foreign investment so that foreigners dominate the strategic position while local people only work in a low-income position so that tourist visits do not have a significant effect on reducing poverty. The study of poverty has a long history. It can be traced back to the work of Charles Booth. His extensive survey of economic conditions in London during the last decades of the 19th century and depicting a series of social deprivation maps have been recorded as the first modern social surveys (O'Day and Englander, 1993). However, concerns with poverty surveying and registering could have begun much earlier in the nineteenth century, with Engel's The Condition of the Working Class in England in 1844 and Mayhew's London Labor and the London Poor in 1861 (Hillier, 1998; Hillier, 2002). In analyzing the spatial configuration of poverty, a detailed analysis of local variations is essential. Although some studies from population experts and geographers relate to household-level statistics, and in some areas, detailed information regarding this data is publicly available (Hillier, 2002; Benenson and Omer, 2003). In some regional cases, this data is not publicly available due to privacy and confidentiality concerns (Boyle and Dorling, 2004). Previous studies have focused on poverty, except that it has concentrated more on poverty's social causes than its morphological effects (O'Day and Englander, 1993).

The geographic income deprivation pattern shows that the level of deprivation in each district or city in a particular group and the environmental scale varies (Gumilar et al., 2018). In these studies, analysis of the spatial aspects of deprivation and poverty is based on the census (Noble et al., 2000; Orford et al., 2002; Ballas, 2004). Several recent studies have also used multiple geographic scales to inform local policies (Hillier, 2002; Neil et al., 2018). In certain conditions based on the perspective of morphology, several regional factors such as the natural environment, regional culture, economic development, rural forms, local laws, development needs, all of which color the spatial characteristics of rural areas based on (Gill et al., 2008; Neef and Neubert, 2011; Eames et al., 2013; Anna et al., 2017; Neil et al., 2018).

The idea of this research departs from empirical reality about villages that are still covered with welfare issues. So the concentration of this study is on poverty that occurs in the village and the relationship between poverty with social structures that specifically depart from social morphology. The deprivation that occurs in Parakansalak Village is closely related to the reading of the social morphology. To further strengthen poverty in a review of social morphology, some complexities can be translated as physical space and social space.

\footnotetext{
* Corresponding author
} 
Physical space is related to the physical environment (for example, land, land area, and land conditions) and regional climate. In comparison, social space is connected to community demographics (for example, employment and income). Between physical space and social space, it is then constructed socially and adaptively as time goes by, creating social structure. This social structure reinforces how poverty can be maintained in such a way since then and continues today. As mentioned earlier, all of that moves in the spaces, which ultimately formulates a social structure in the form of Poverty in the Parakansalak Village.
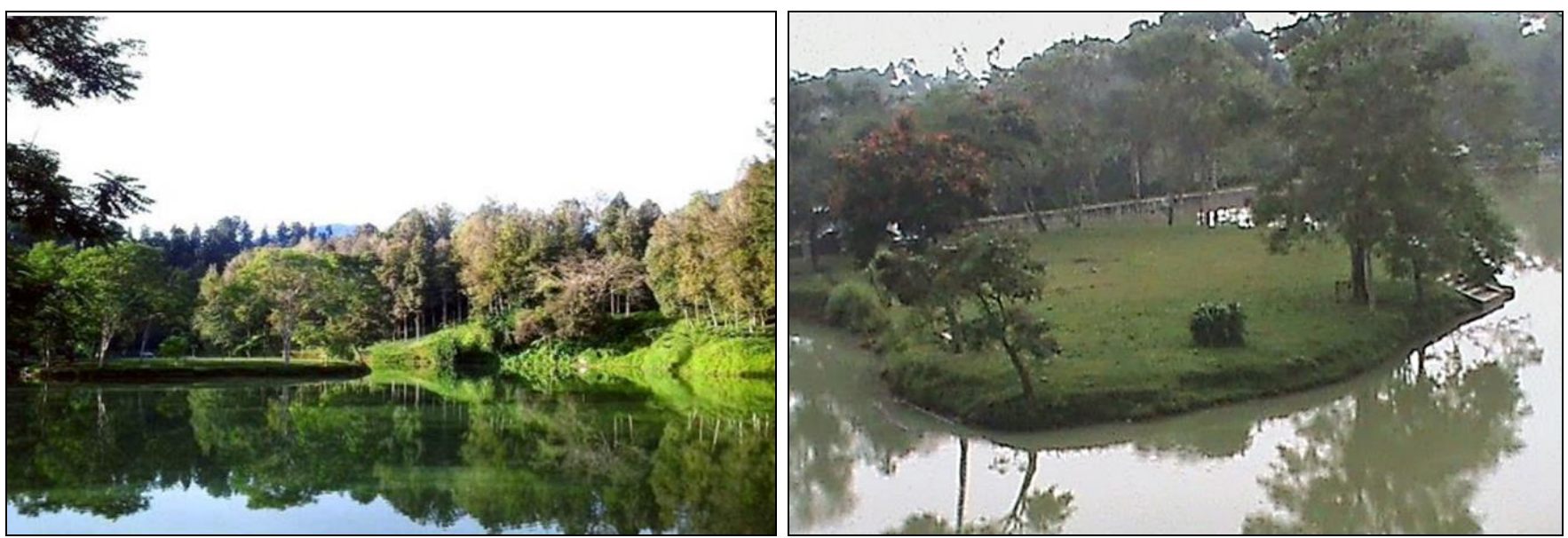

a. Situ Sukarame
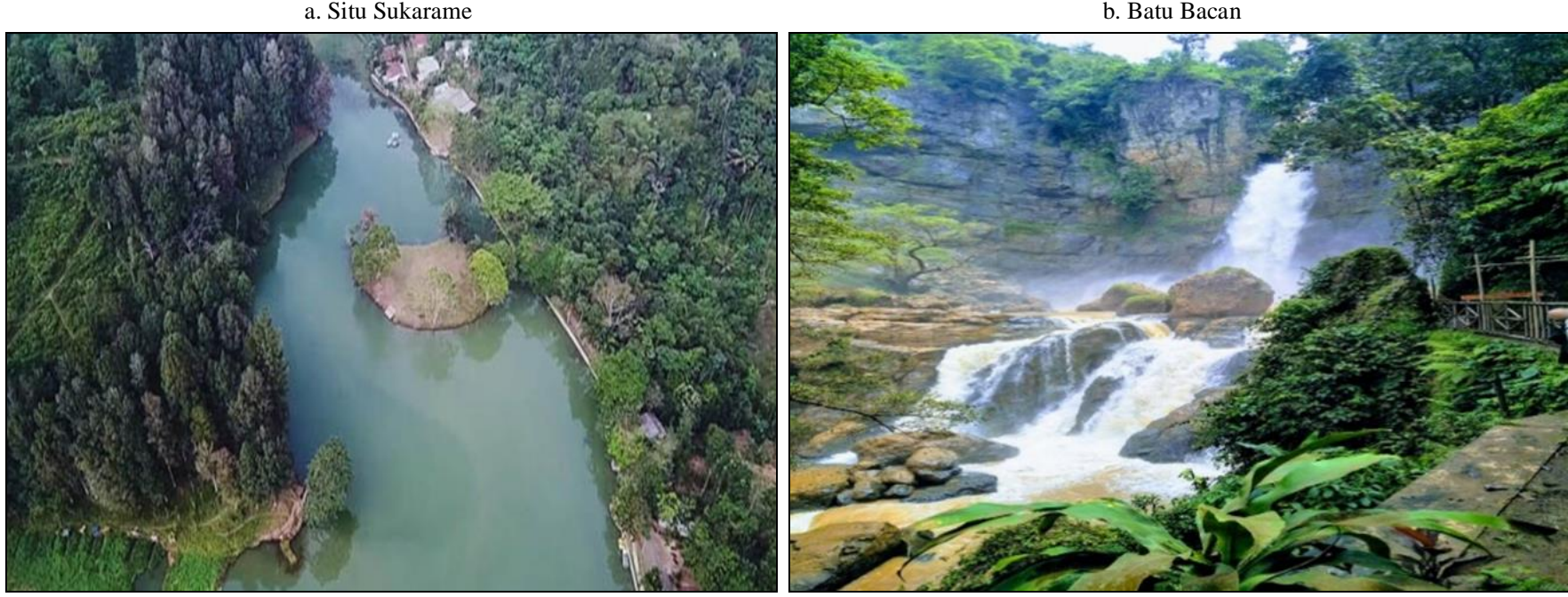

c. Batu Karut
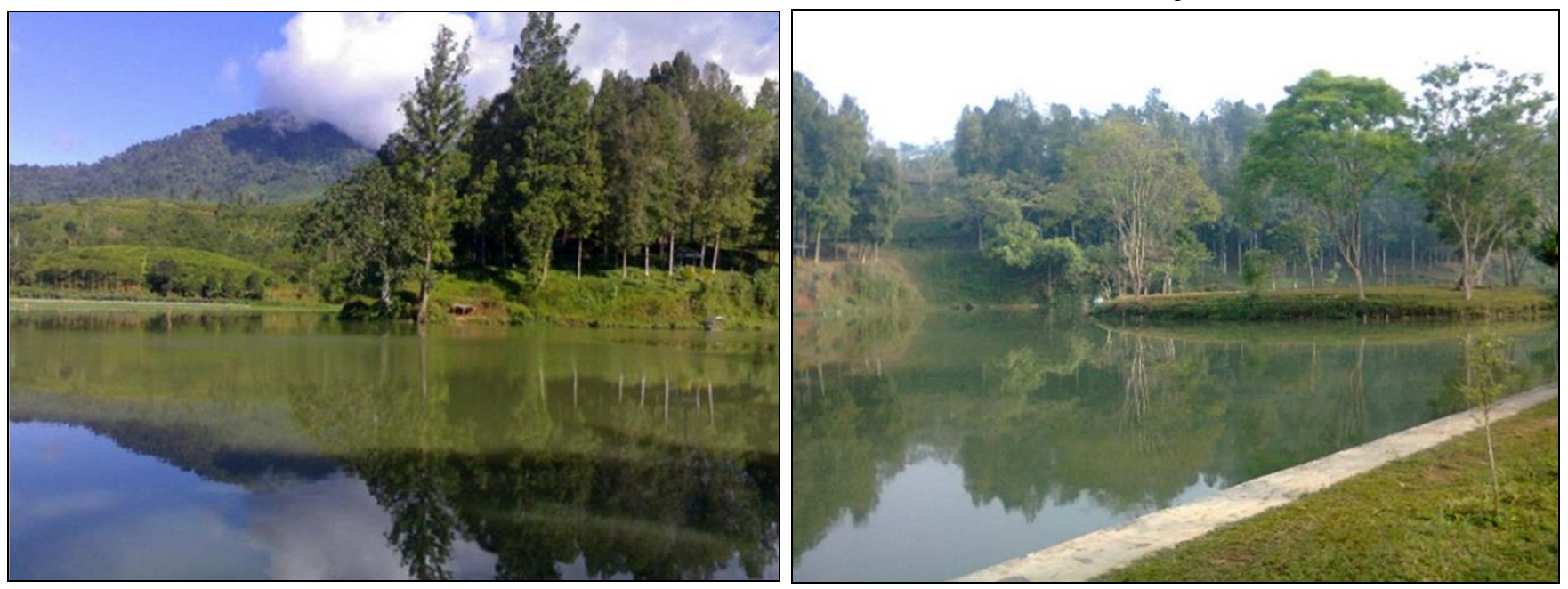

e. Situ Gunung

f. Karang Numpang

Figure 1. Favorite tourist spots in Parakansalak Village

Tourism has been perceived as a meaningful diversification of the economy. More importantly, tourism is professed as being able to alleviate poverty among the poor, the majority of whom live in tourism resource-rich areas (Ashley and Roe, 2002; Scheyvens, 2009; Matarrita et al., 2010; Sakata and Prideaux, 2012; Graci, 2013; Mlambo and Ezeuduji, 2020). Therefore, tourism becomes an ideal candidate for poverty alleviation in Indonesia due to its labour-intensive nature, enabling it to employ disadvantaged community members with very little formal training, e.g., women and youth. Besides, tourism utilizes the poor's natural and cultural resources to utilize these resources for their benefit. However, tourism is a private sector business and, therefore, is controlled by market forces. By its 
very nature, tourism is geared to serve the tourist's and investors' interests and, therefore, does not automatically improve the community's poorer members (Sakata and Prideaux, 2012; Graci, 2013; Rizal et al., 2020). From the formulation of the problem, this study was built from the nature of the relationship between poverty, rural communities, and the idea of social morphology. The holistic of these concepts results in an explanation that can holistically answer what the research questions formulate. The purpose of this study is focused on answering the questions that have been raised, namely, to analyze and understand the conditions of poverty in rural areas caused by social morphological conditions in Parakansalak Village, Sukabumi District, West Java.

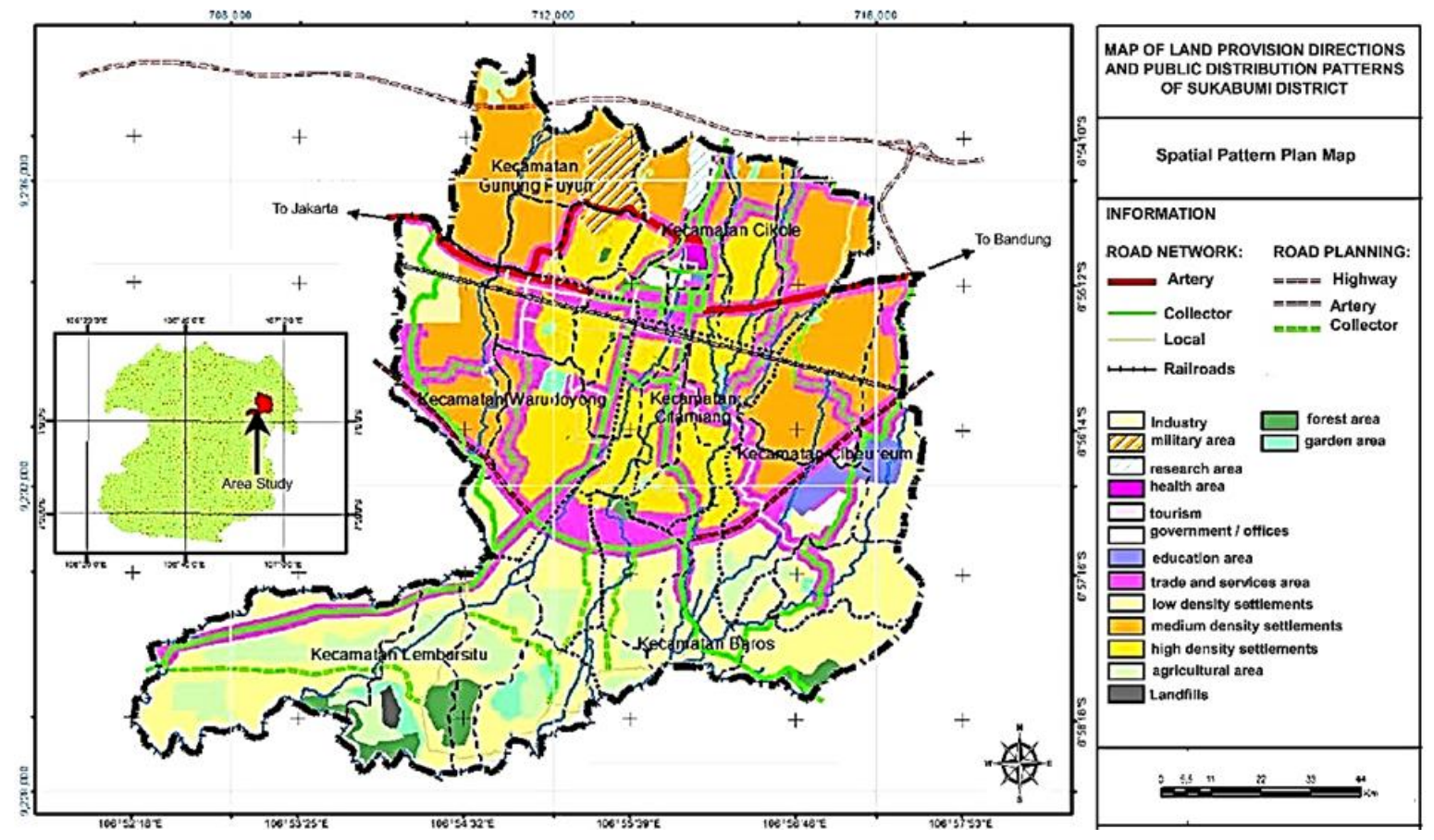

Figure 2. Map of Parakansalak Village in Sukabumi District, West Java Province

Parakansalak Village is part of the Parakansalak sub-district, Sukabumi District (Figure 2). This village is the youngest village that was definitively newly established in 2007 before it was part of the Lebaksari Village. Historically in 2005, Lebaksari Village had experienced social upheaval that smelled of local politics, namely the rise of protests directed at the Lebaksari Village apparatus by residents of several hamlets in the upper part of this village, one of them is Parakansalak Hamlet. This was triggered by residents' dissatisfaction with some of the hamlets who thought that development in the village of Lebaksari experienced stagnation, and the welfare of the residents did not increase significantly. In 2005 a temporary village government was formed before it was ratified in 2007 when the village already had a definitive set. Since 2007, it was the birth of Parakansalak Village, which has taken place in the village administration until now.

Parakansalak Village had many tourist objects that are domestic tourist destinations in Indonesia. This tourist village has a stunning natural panorama (Figure 1). The village is surrounded by heterogeneous forests covered with pine and resin trees, and there is also a stretch of tea garden, which makes the scenery in this village even more exotic. The cold and fresh air adds to the attractiveness of this tourist village. This village is one of the most popular and favorite tourist spots among Indonesian photographers.

\section{MATERIALS AND METHODS}

This study used a qualitative approach that begins with the assumption and use of theoretical and conceptual interpretation frameworks that shape or influence the study of research problems related to the meaning imposed by individuals or groups on a social or human problem. This research takes the type of in-depth qualitative description (thick description).

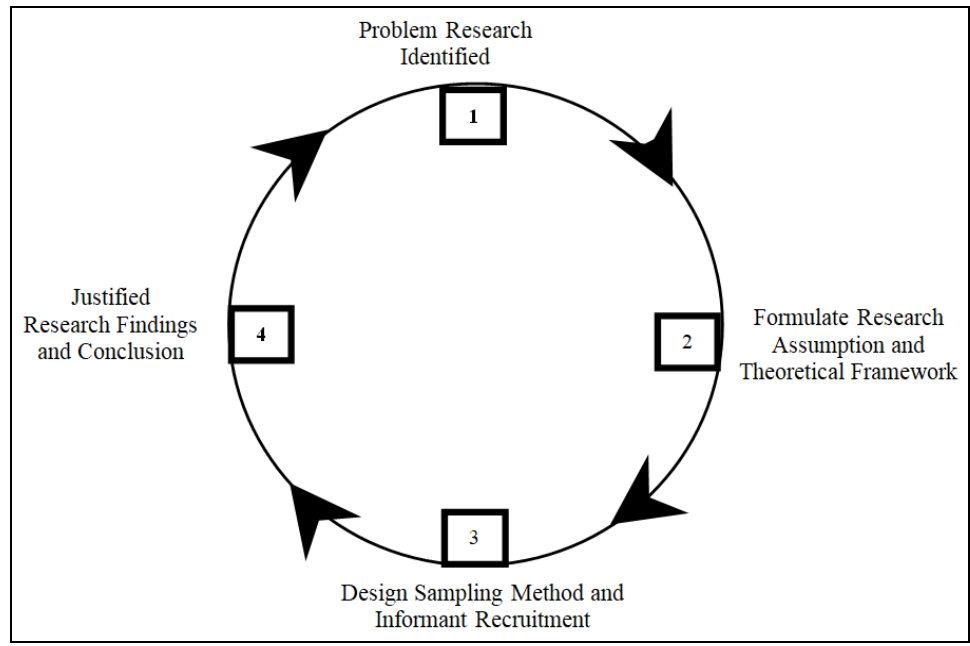

Figure 3. Methodology Research Framework 
This research focuses on the form of villagers' poverty regarding spatiality's social morphological aspects, namely the social use approach in public space and in-between spaces and villagers' social activities.

Parakansalak sub-district after the transfer of the central government and capital of Sukabumi district to Palabuhanratu City, the location of the Parakansalak sub-district government area is to the north of the government capital city of Sukabumi district, with a non-rice field area of 5,669.68 hectares, rice field: 757.60 hectares, the total amount: 6,426.68 hectares. Geographical relationship, in terms of land conditions in the working area of the Parakansalak sub-district government, the situation is sloping and hilly with an altitude from sea level of more than $700 \mathrm{~m}$ to $900 \mathrm{~m}$, with an air temperature of at least 18 degrees Celsius and a maximum of 28 degrees Celsius with average rainfall (Parakansalak sub-district office, 2019). The population living permanently in the working area of the Parakansalak sub-district government is spread across six villages that are, on average, presented in a balanced way. The details are as follows: Parakansalak Village: 7,488 people; Lebaksari Village: 6,134 people; Sukakersa Village: 6,666 people; Sukatani Village: 5,909 people; Bojongasih Village: 6,106 people; Bojonglongok Village: 6,913 people. They represented a combination of the regularity of income, work status, and industrial occupation (because some fields were seasonal and thus irregular) (Parakansalak sub-district office, 2019).

The spatial information calculation methods in this study involve (1) the length, curvature, and direction of the linear features, (2) the area, perimeter, and shape of the planar features; (3) topology, order, distance, and orientation of spatial relationship among spatial entities; (4) distribution center, shared space, distribution density, and distribution axis of spatial distribution. This research choos es rural settlements promoted by different topographical and geomorphological conditions, other regional cultural characteristics, and various leading agribusiness in the Sukabumi District in terms of selecting samples. At the same time, the homogeneous distribution of exampl es within the Sukabumi District was also focused on ensuring that the study could reflect the morphological characteristics and problems of rural settlements in all villages to the utmost extent (Figure 1). The study will eventually digitize critical areas in both the latter maps, each of which covers a significant Parakansalak sub-district area, including a prosperous and poor village. We aim to compare and analyze change over the years, separating the field surveys and comparing them with the most recent census. We have sought to contend with the theoretical and methodological challenges of analyzing the relationship between spatial and social factors.

Concerning data collection, qualitative data are the primary choice. Data collection is based on triangulation, where interviews, documents, and unique mapping are combined. A combination of qualitative and quantitative data is possible (Eisenhardt, 1989; Davis and Eisenhardt, 2011). Data analysis is conducted via the search for within-case patterns and cross-case patterns. Systematic procedures are undertaken to compare the emerging constructs and relationships with the data, eventually leading to graph theory (Hillier, 1998).

The interview guide's instruments were the interview guide, a recording device, and the interview result recording sheet. This instrument is used to assist in collecting data. Interview guidelines were used to interview three informants: first, key informants, namely the head of Parakansalak Village, who were considered to have general information regarding the research area. Second, the main informant, namely the leader of the farmer group who is deemed to have detailed information regarding the condition of the farmer and the village area, and third, the supporting informant, namely the agricultural extension agent, with the consideration of having additional relevant information related to the main informant. The recruiting informants' pattern analyzed the informants' role in collecting research data to produce relevant information (Patton, 2002). Data obtained from the three informants are used as comparative data, which are considered to improve data quality and draw research conclusions from the data. Data were taken from public and private data, informants' materials, official village, and government publications. The data was measured, coded, and triangulated. Iterati on between cases and theory and considering the relevant literature provided the basis for developing a theoretical framework (Figure 3).

\section{RESULTS DISCUSSIONS}

\section{Social use approach in public spaces}

Sociologist William Whyte's (1980) research is one of the primary studies on social use in public space. It is based on direct observation to study the use frequency of individual squares in New York in the usual and ordinary way. Whyte (1980) placed cameras to capture the pedestrian flow and social gatherings in the streets. The main results showed that users were the main attraction factor for other users. The users chose the spaces already occupied and dense by preferring the outer limits or borders for passive activities. Whyte (1980) concluded that places are correlated with the number of areas to sit on and their proximity to the street. Several studies confirmed Whyte's results, wherein other users' visibility is an essential factor in space occupation (Whyte, 1980; Jingnan et al., 2007; Paroda, 2012; Ray et al., 2012).

These activities take place in favorable weather conditions. Social activities depend on others' presence in public spaces (Rola et al., 2002; Daraba, 2015). They can be children's games, greetings, discussions between people, ordinary activities of all kinds, and passive contact, defined as watching and hearing others. These activities can also be described as "resulting" actions because they occur spontaneously due to movement and people's presence in the same spaces. Sociologist states that a social activity takes place when two people meet in the same area, see each other, and listen to each other, all of which are forms of contact and social interaction (Collins, 1983; Collins, 1993; Guy, 2010; Dael et al., 2012; Shen et al., 2013; Schmidttraub et al., 2017; Rizal et al., 2019).

Open spaces vary from squares to intermediate spaces with linear forms with a certain degree of social freedom, for example, streets, roads, and alleys. The intensity of social activities in the street can be ensured in areas with reduced traffic and available facilities. Highconcentration residential neighborhoods where public spaces are inadequate to push people to use the roads as a means of interaction. Rizal et al. (2020) find a strong relationship between spatial configuration, accessibility, and social interactions. These factors can be facilitated by accessibility and spatial design. The fluidity of pedestrian movement can contribute to the increase of encoun ters between urban space users. Snapp et al. (2002) emphasize the importance of in-between spaces as a support for social life and their development of social interactions between users. Poverty is a concept that never runs out for discussion. Even though the conditions alleviation programs also never subsided by the government, often the results are still far from encouraging (Whyte, 1980; Jingnan et al., 2007; Paroda, 2012; Ray et al., 2012; Rizal et al., 2019; Rizal et al., 2020). So indeed, it takes interdisciplinary knowledge to translate what is meant by poverty.

The problem of poverty in rural areas in this study is interpreted as a form of culture related to rural community life. This problem is also reinforced by Clifford Geertz's expression of a culture that contains complex networks that have both signs and symbols in the form of routines and habits (Zhang et al., 2011; Vuillot et al., 2016). These routines and traditions exist in various mental construction states based on social experience, are local and specific, and depend on the party doing it (Yuan, 2018).

On the other hand, social morphology is also strongly associated with spatial or spatial ideas, like Aminah et al. (2015). They say that space is defined by the relationship between the entities contained in it. The most exciting and influential theory of space that forms this research work is a spatial organization with daily life structure related to poverty in rural areas. It is reinforced that the import of mixer processes from the production of blank physical space and not the direct upshot of the epitope of physical space (Zhang et al., 2013). Translating the village community at this time, we will be confronted with so many sociological and political-administrative definitions that 
will relate to one another. However, for the sake of this research, understanding the village community refers more to the sociological aspect while still not ignoring its political-administrative understanding. Direct interviews certainly make the whole picture. The interview is a step in finding knowledge and experience of a phenomenon in a particular setting and holistic setting. This set consists of a holistic accumulation of behavior, perceptions, actions, and various critical supporting elements. From the results of the village social mapping conducted at the beginning of this study, it is known that the number of residents' livelihoods can be described in the following table.

Table 1. Livelihoods of Parakansalak Village Communities (Source: Parakansalak sub-district office, 2019)

\begin{tabular}{|c|l|c|}
\hline No. & Livelihood & Percentage \\
\hline 1. & Agriculture & 87 \\
\hline 2. & Government / public services & 1 \\
\hline 3. & Trading services & 3 \\
\hline 4. & Skill/carpentry services & 5 \\
\hline 5. & Other Services (motorcycle taxi, driver, pedicab driver) & 2 \\
\hline 6. & Industrial Sector & 0 \\
\hline 7. & Other sectors (informal labor, helpers) & 2 \\
\hline & Total & 100 \\
\hline
\end{tabular}

The data above is based on the Parakansalak village government statistical report data. The data can reflect residents' views regarding their social conditions related to residents' work in Parakansalak Village. The data also shows how residents perceive themselves as a large collective with a main livelihood in agriculture (Daraba, 2015). There are 2 (two) categories of farmers in this village, namely the first category of very small landowners, and the second, smallholder farmers or farm laborers in large numbers. Farmers, as the majority work, present a very striking picture of the economy and life. The landowner farmer is a wealthy citizen who can easily be marked by their lovely large building. Small and semi-permanent houses tend to be slums and are characterized by the limited or narrow place, and the yard is poor farmers, aka residents whose jobs are as farm laborers. Parakansalak Village, with its position in the mountainside area, has environmental conditions characterized by forests and hills with a little flat area. On top of the landscape of forest lands like that, citizens from the beginning of history began to develop their lives so that physical space was formed and lived. Living in the sense that citizens begin to occupy (live and live) by utilizing natural forest resources so that the forest environment's life is complicated with humans' presence (Paroda, 2012; Daraba, 2015). Life is a back effect on people or people who occupy the forest environment that bring significant benefits to humans or their citizens - meaning that the environment with the forest's natural resources provides services that can support the people who inhabit it.

The physical environment in this area, once a jungle, is starting to open because of the interest in making settlements and farming (Aminah et al., 2015; Daraba, 2015). The living space and physical environment process are evident from a physical stretch of the landscape or area gradually changing from the wilderness into agricultural lands and residents' dwellings.

This situation continues until the number of citizens continues to grow, and utilizing the natural environment in this region is intensified by people who start to occupy it (Paroda, 2012; Daraba, 2015). With the limitation of the area and tandem with the growing number of residents, there was an intensification of land by the Parakansalak community. However, the land intensification carried out by the residents did not experience high progressivity because they learned from the experience of agriculture over time that in this region, taking into account the climate is only ideal for certain types of plants, such as rice, corn, tobacco, onions, and chilies (Aminah et al., 2015; Daraba, 2015). But whatever it is, basically, since their existence in the Parakansalak region that utilizes the physical environment explicitly with the practice or intensification of agriculture, there has been a production of space in the Parakansalak environment by its citizens.

This spatial production takes place with far-reaching consequences for their spatial practices in such a way as the manifestation of spatial actions makes the villagers read as agricultural communities (Whyte, 1980; Jingnan et al., 2007; Paroda, 2012; Daraba, 2015; Aminah et al., 2015). More clearly will be explained further on the production of this space in the next sub-discussion subjects.

\section{Social Morphology and the Poverty of Parakansalak Residents}

Agriculture, with all its forms of practice, is an effort of Parakansalak villagers to produce their living space. The most crucial area for their existence is how the Parakansalak region's landscape is used in such a way as agriculture for the fulfillment of its economic needs through the planting of seeds of productive plants by processing plots of land (Jingnan et al., 2007; Paroda, 2012). Such spatial production through agriculture is evident from the actions of residents who had begun by opening up forest areas or commonly referred to as land extensification, which is an effort to improve agriculture by expanding new agricultural land. Thus, the spatial production continues from land extensification with traditional techniques that are no longer possible, leading to the land intensification.

However, this intensification attempts to increase agricultural output by optimizing existing agricultural land because land clearing has not been possible since the Sukabumi regional government imposed village administrative boundaries. In intensifying agriculture, they use the methods generally carried out by farmers, namely trying to cultivate the land following their planting interests, making irrigation to present water needs for plants, they also choose the seeds to be planted, they also fertilize and if there is their pest will soon eradicate (Zhang et al., 2011; Vuillot et al., 2016). What they do in agricultural terms is often referred to as five farming.

The important thing done by the Parakansalak villagers in the production of their agricultural space is to pay attention to the climate. This factor becomes very important for agricultural businesses (Daraba, 2015). Indonesia will be divided into two seasons, namely the rainy season and the dry season. These two seasons determine plant types to be planted as their agricultural strategy with their respective climates.

In addition to climate factors, they also read commodity factors increasing demand in carrying out their agricultural space production activities (Aminah et al., 2015). These two general factors make their land management and spatial production efforts seem very typical from year to year due to their dependence on both aspects, climate and commodities (Jingnan et al., 2007; Paroda, 2012; Daraba, 2015).

From the pattern of the growing season, it is seen how their production of agricultural space is very dependent on the presence of climate or season. The dry season, which usually falls from April to October, will be widely used by villagers by growing crops such as tobacco, corn, onions, and chilies. In the rainy season, which falls from November to March, many of their lands will be used for rice. In the dry season, in particular, it will be seen how crop diversification is more visible than in the rainy season (Parakansalak Sub-district office, 2019).

What farmers do in Parakansalak Village is seen that they are farmers as cultivators of land in rural areas, where rational considerations or choices become the behavior of residents in this village. The most important adaptation is the problem of adaptation to climate or season (Daraba, 2015). The above has explained that they live in two climates or seasons, namely the dry season and the rainy season. The morphology of these two seasons creates specific different social patterns but are still related to one another. 
The rainy season is considered the most severe season because it does not generate much cash income. After all, rice farming results in the rainy season are not sold to the market but consumed by themselves. This response is a form of adaptation to the coming climate or dry season in the coming months, which seems to be significantly helped by the stock of rice or rice in their homes. This situation was strengthened by the Head of Parakansalak Village, Asep Sobari, in his interview:

".. Officials contact us and record groups of farmers who cannot afford to get help from the village ministry; we have to wait if they need to contact us, so we come. help all explain to them .. ".

Although the amount of rice obtained from all residents varies, the generally accepted difference is that $30 \%$ of the rice yie lds are for agricultural laborers, and $70 \%$ of the rice harvest is for land or rice owners (Daraba, 2015; Vuillot et al., 2016). The average landowner or landowner will make an annual adaptation that is quite successful in facing the dry season and, at the same time, enter the rainy season next year. Unlike the residents who work as agricultural laborers who yield $30 \%$ of the average rice harvest still does not meet his needs - let alone reach the dry season or the rainy season in the coming years. For up to the next 2-3 months, the rice yield is not sufficient for the needs until the season changes next year. These farm laborers must be done because adaptation is more difficult to avoid changing seasons into the dry season, even if it's only for 2-3 months (Zhang et al., 2011; Daraba, 2015; Vuillot et al., 2016).

The adaptation of new technologies by subsistence farmers using sustainable intensification is a complex process. This proces $s$ is not easy because it involves many competent parties (Benenson and Omer, 2003; Aminah et al., 2015; Daraba, 2015). In Parakansalak village, agricultural technology transfer is almost entirely dependent on government assistance, both central and local. The new technology development system in agriculture is a system introduced by the government to farmers (top-down model), usually through extensive processes. This system's weakness is that extension workers are not involved in the practical problems faced by farmers. The courses or training taught to extension agents are relatively simple, the training time does not follow a seasonal cycle, and the training time is somewhat limited. So that extension workers do not understand the problems of farmers in the field.

With an ineffective extension process, it results in low effectiveness of the transfer of knowledge to farmers. Farmers' understanding in villages is not good enough regarding agricultural practices, the variability of land and ecological areas, and understanding of markets and infrastructure (Zang et al., 2011; Vuillot et al., 2016). Meanwhile, for farmers applying new technology often requires more time, effort, and capital investment. On the other hand, this new technology does not guarantee higher profits for the farming business. The top-down method of knowledge transfer does not help farmers to avoid risks to their farming. Farmers also need time to understand new technologies and their relationship to agricultural production. Many of these problems result in poor perceptions of farmers about changes that have occurred in their agriculture. Therefore, it is essential to change the model in transferring knowledge into farmer actions.

Previously, the so-called agricultural space production, as described above, will ultimately influence the formation of their social space, which is more abstract but applies to their living arrangements. This circumstance is built due to its production with its agricultural characteristics as the environment they process (Snapp et al., 2002). For more details, it will be explained how the production of space with the treated environment makes their farming characteristics and forms the social area, which we commonly refer to as social structure.

First, the area that was once a wilderness on the mountains' slopes by the predecessor residents was opened to make them productive as agricultural land. Second, the difference between able-owned people who own land and less-able people who do not own land has a specific pattern of relations between the two in the context of land management or agriculture. It can then be seen the pattern or social structure of residents' daily lives in Parakansalak. This situation is the reality of social structure built in this village due to the attachment of one element to other elements in aspects of their daily lives (Zang et al., 2011; Vuillot et al., 2016).

Modern high input agriculture - based on decades of investment, research, and innovation - has been implemented. More food has been produced on less land with fewer resources at a lower cost to consumers while also creating greater prosperity. In parts of the world where smallholder farmers dominate, investment in agricultural innovation can be life-changing (Snapp et al., 2002; Benenson and Omer, 2003; Jingnan et al., 2007; Paroda, 2012; Daraba, 2015; Aminah et al., 2015). Speaking of the social structure in Parakansalak Village, it cannot be separated from the reading of the social morphology in this village, which means the determination of physical environmental factors, both natural and climate (as domains) combined with social-economic life (as a result) that takes place in the lives of Parakansalak villagers. There is a form of production of space, which consequently makes it a way of social structure. The social system in question is a fabric that presents its difficulties for most citizens to get out of a condition called poverty (Noble et al., 2000; Orford et al., 2002; Ballas, 2004). As a result of an interview with the agricultural extension agent of Parakansalak Village, Sutisna stated:

"... We started getting agricultural production facilities assistance from 2015 to 2018, then they were cut off because there were villages that needed more. Hopefully, this year there will be more .. ".

The regional characteristics of rural settlements' spatial form reveal that the rural spatial evolution follows a series of similar rules, ensuring that the accommodations are relatively stable and different from those in other regions during the evolution process. In the practice of rural planning and construction, however, planners often focus on the importance of society, economy, and culture, neglecting the role of space form, which, to a certain extent, destroys the organic and various rural settlement spatial texture and hinders the inheritance of the traditional rustic spatial form (Griffith, 1942; Gospodini, 2006; Echenique et al., 2012; Neil et al., 2018).

With this social morphology, it will also present the effects of social life structured in such a way as a social order for citizens' lives in Parakansalak Village. Problems arise when this social structure is so strong that collectively influences the behaviors of citizens, an essential critical action is the economic behavior of citizens through the agricultural domain, which for the bulk of citizen /majority feels difficult and insufficient to meet their needs - which in words others as a form of impoverishment (Hillier, 1998; Hillier, 2002). Concerning this condition was the response by expressed of the leader of the farmer group, Ubed Ikin, in his interview as follows:

"... Indeed this program is aimed at the poor in this area, through groups formed by the community themselves to develop their farming businesses so that that income can increase. ..."

From there, we can read that the poverty that occurred in Parakansalak Village, which until now continues to plague the majority of villagers, starts from the land and the nature of land ownership, production of their living space through agriculture to become the social structure that supports it and ultimately impacts on "permanence" poverty conditions of the majority of residents in this village. Then the collapse of national food security is just a matter of time if farmers are still marginalized.

Under the evolutionary mechanism of comprehensive control of internal factors and external factors in the evolution of rural settlements, the processes of 'organism's deprivation, inheritance, and mutation in genetics can be analogized. The evolution law of rural settlement space has a pronounced similarity with biological evolution. In this paper, the concept of "morphogenesis" is introduced to classify rural spatial 
forms' potential factors at a more comprehensive and in-deep level. Referring to the idea of genes in biogenetics, the morphological characteristics that can reflect and control the rural settlements' spatial form are called rural settlements' morphogenesis (Pu et al., 2013; Pu et al., 2018). Social morphology is based on environmental conditions or surrounding conditions. The nature of land ownership, climate/season conditions, determination of crops based on seasons, and market potential (commodities) to citizens' work process is a form of rural communities' social-economic life (Hillier, 1998; Hillier, 2002; Zang et al., 2011; Vuillot et al., 2016). All of this is a form of spatial production, which presents most residents' general characteristics in Parakansalak Village. Likewise, with all their difficulties, they will face the rainy and dry seasons again in turn. For that, they will always feel challenges that are almost unbroken from time to time.

\section{CONCLUSION}

What can be concluded from the explanation of the lives of the community members in Parakansalak Village is that in this village community it is a portrait of the face of poverty in an area that has a unique character, namely concerning the production of space in the physical, natural, and social environments which are forms of from social morphology that gives effect to the formation of the social structure of the life of villagers. From each of them, it can be seen that the impact of spatial production as a form of social morphology indeed illustrates the conditions of poverty in this village.

This is supported by the results found in this study which concisely indicate that the poverty conditions in this village are caused by several primary factors, namely: a) the majority of residents as farmers have a high degree of dependence on the land that is their source of livelihood in agriculture, b) in the case of agricultural space production which is very dependent on the climate / season, namely the rainy season and the dry season with different types of plants between the two seasons, c) the level of agricultural production results both from the two seasons is not enough to provide benefits for fulfillment the needs of the majority of the poor as farm workers because of the lack of ownership of agricultural land, limited land is only owned by a handful of wealthy citizens, and d) the dependence of the majority of the poor as agrarian laborers on the rich as landowners is closely related to spatial production (both space in physical environment, nature, and space of social environment), which can be read as a form of social morphology that ultimately creates a social structure called poverty.

\section{Acknowledgments}

The authors wish to thank Universitas Padjadjaran and the Center for fisheries development and regional management studies, supporting the study.

\section{REFERENCES}

Aminah, S., Sumardjo, Lubis, D., \& Susanto, D. (2015). Strategy for increasing small farmers' empowerment towards food security. Sosiohumaniora, 18 (3), 255-263. https://doi.org/10.24198/sosiohumaniora.v17i3.8343

Anna, Z., Agus, A.H.S., Maulina, I., Rizal, A., \& Hindayani, P. (2017). Biological Parameters of Fish Stock Estimation in Cirata Reservoir (West Java, Indonesia): A Comparative Analysis of Bio-Economic Models. Biodiversitas, 18 (4), 1468-1474. https://doi.org/10.13057/biodiv/d180423

Ashley, C., \& Roe, D. (2002). Making tourism work for the poor: Strategies and challenges in South Africa. Development Southern Africa, 19, 61-82. https://doi.org/10.1080/03768350220123855

Ballas, D. (2004). Simulating poverty and income inequality trends based on 1991 and 2001 census data: a tale of two cities. Area, 36, 146-63. https://doi.org/10.2457/srs.42.163

Benenson, I., \& Omer, I. (2003). High-resolution census data: a simple way to make them useful. Data Science Journal, 2, 117-27. https://doi.org/10.2481/dsj.2.117

Boyle, P.J., \& Dorling, D. (2004). Guest editorial: the U.K. census: remarkable resources or bygone of the 'pencil and paper 'era'?. Area, 36, 101-10. https://doi.org/10.1111/j.0004-0894.2004.00207.x

Collins, R. (1983). Micro methods as a basis for macrosociology. Journal of Contemporary Ethnography. 12(2), 184-202. https://doi.org/10.1177\%2F00 98303983012002004

Collins, R. (1993). Emotional energy as the common denominator of rational action. Rationality and Society. 5 (2), 203-30. https://doi.org/10.1111/14685914.00095

Dael, N., Mortillaro, M., \& Scherer, K.R. (2012). Emotion expression in body action and posture. Emotion, 12 (5), 1085-101. https://doi.org/10.1037/a0025737

Daraba, D. (2015). Factors affecting the poor community empowerment program's success in north polongbangkeng district, Takalar Regency, South Sulawesi Province, Sosiohumaniora, 17 (2), 165-169. https://doi.org/10.24198/sosiohumaniora.v17i2.7305

Davis, J.P., \& Eisenhardt, K.M. (2011). Rotating leadership and collaborative innovation: recombination processes in symbiotic relationships. Administrative Science Quarterly, 56, 159-201. https://doi.org/10.1177\%2F0001839211428131

Eakin, H., \& Luers, A.L. (2006). Assessing the vulnerability of social-environmental systems. Annual Review of Environment and Resource, 31, 365-394. https://doi.org/10.1146/annurev.energy.30.050504.144352

Eames, M., Dixon, T., May, T., \& Hunt, M. (2013). City futures: exploring urban retrofit and sustainable transitions. Building Research and Information, 41 (5), 504-516. https://doi.org/10.1080/09613218.2013.805063

Echenique, M., Hargreaves, A.J., Mitchell, G., \& Namdeo, A. (2012). Growing cities sustainably. Journal of The American Planning Association, 78 (2), $121-$ 137. https://doi.org/10.1080/01944363.2012.666731

Eisenhardt, K.M. (1989). Building theories from case study research. Academy of Management Review, 14, 532-550. https://doi.org/10.5465/amr.1989.4308385

Gill, S.E., Handley, J., Ennos, R., Pauleit, S., Theuray, N., \& Lindley, S. (2008). Characterizing the urban environment of U.K. cities and towns: A Template for Landscape Planning. Landscape and Urban Planning, 87, 210-222. https://doi.org/10.1016/j.landurbplan.2008.06.008

Gospodini, A. (2006). Portraying, classifying, and understanding the emerging landscapes in the post-industrial city. Cities, 23(5), 311-330. https://doi.org/10.1016/j.cities.2006.06.002

Graci, S. (2013). Collaboration and partnership development for sustainable tourism. Tourism Geographies, 15, 25-42. https://doi.org/10.1080/14616688. 2012.675513

Griffith, T. (1942). Environment, village, and city: a genetic approach to urban geography, with some reference to possibilism. Annals of the Association of American Geographers 32(3), 1-67. https://doi.org/10.1080/00045604209357229

Gumilar, I., Rizal, A., \& , Sriati, S.P.R. (2018). Analysis of consumer behavior in decision making of purchasing ornamental freshwater fish (case of study at the ornamental freshwater fish market at Peta Street, Bandung). IOP Conference Series: Earth and Environmental Science, 137(1), 012081. https://dx.doi.org/10.1088/1755-1315/137/1/012081

Guy, C. (2010). Development pressure and retail planning: a study of 20-year change in Cardiff. U.K. The International Review of Retail, Distribution, and Consumer Research, 20 (1), 119-133. https://doi.org/10.1080/09593960903498250

Hillier, B. (1998). The common language of space: a way of looking at cities' social, economic, and environmental functioning on a common basis. Journal of Environmental Science, 11, 333-49. https://doi.org/10.1057/udi.1996.5

Hillier, B. (2002). A theory of the city as an object: or, how spatial laws mediate the social construction of urban space. Urban Design International, 7, 15379. https://doi.org/10.1057/palgrave.udi.9000082 
Jingnan, Huang, X.X, Lu, B, Jefferey M., \& Sellers, C. (2007). A global comparative analysis of urban form: Applying spatial metrics and remote sensing. Landscape and Urban Planning, 82(3) 184-197. https://doi.org/10.1016/j.landurbplan.2007.02.010

Matarrita, C.D., Brennan, M.A., \& Luloff, A.E. (2010). Community agency and sustainable tourism development: The case of La Fortuna, Costa Rica. Journal of Sustainable Tourism, 18, 735-756. https://doi.org/10.1080/09669581003653526

Mbaiwa, J.E. (2005). Enclave tourism and its socio-economic impacts in the Okavango Delta, Botswana. Tourism Management, 26, 157-172. http://dx.doi.org/10.1016/j.tourman.2003.11.005

Mlambo, S.S., \& Ezeuduji, I.O. (2020). South Africa's Kwazulu-Natal Tourism Destination Brand Essence and Competitiveness: Tourists' Perspectives. GeoJournal of Tourism and Geosites, 32(4), 1195-1201. https://doi.org/10.30892/gtg.32401-557

Neef, A., \& Neubert, D. (2011). Stakeholder participation in agricultural research projects: a conceptual framework for reflection and decision-making. Agriculture and Human Values, 28, 179-194. https://doi.org/10.1007/s10460-010-9272-z

Neil, D.W., Fanning, A.L., Lamb, W.F., \& Steinberger, J.K. (2018). A good life for all within planetary boundaries. Nature Sustainability, 1, 88-95 https://doi.org/10.1038/s41893-018-0021-4

Noble, M., Smith, G.A.N., Penhale, B., Wright, G., Dibben, C., Owen, T., \& Lloyd, M. (2000). Measuring multiple deprivations at the small area level: the indices of deprivation 2000. DETR, London.

O'Day, R., \& Englander, D. (1993). Mr. Charles Booth's inquiry: life and labor of the people in London reconsidered. Hambledon Press, London.

Orford, S., Dorling, D., Mitchell, R., Shaw, M., \& Davey, S.G. (2002). Life and death of London's people: a historical GIS of Charles 'Booth's inquiry. Health and Place, 8, 25-35. https://doi.org/10.1016/s1353-8292(01)00033-8

Paroda, R. (2012). Reorienting agricultural research for development to address emerging challenges in agriculture. Journal of Research, 49, 134-138. https://doi.org/10.1016/S2095-3119(19)62592-X

Patton, M.Q. (2002). Qualitative Research \& Evaluation Methods. (3 ed.), California, Sage Publishing

Pu, X., Wang, Z., Gao, L, Huang, Q. (2013). Study on the ordinal value of directionality of the house plane figure in a rural settlement. Architectural Journal 537 (5), 111-115. https://doi.org/ 10.1016/j.egypro.2018.11.292

$\mathrm{Pu}$, X., Wang, Z., \& Huang, Q. (2018). Analysis of the boundary pattern of the rural settlement. Architecture \& Culture 113(8), 48-49. https://doi.org/10.1016/j.egypro.2018.11.292

Ray, D.K., Ramankutty, N., Mueller, N.D., West, P.C., \& Foley, J.A. (2012). Recent patterns of crop yield growth and stagnation. Nature Communication, 3 , 1293. https://doi.org/10.1038/ncomms2296

Rizal, A., Subiyanto, Juahir, H., \& Lananan F. (2019). Freshwater Governance on Limboto Lake in Gorontalo Province of Indonesia. Indian Journal of Public Health Research \& Development, 10 (4), 782-787. https://doi.org/10.37506/ijphrd.v10i4.7084

Rizal, A., Apriliani, I.M., \& Permana, R. (2020). Sustainability assessment of coastal development in the southern region of west java province, Indonesia GeoJournal of Tourism and Geosites, 30(2spl), 808-817. https://doi.org/10.30892/gtg.302spl05-509

Rizal, A., Apriliani, I.M., Permana, R., \& Nurruhwati, I. (2020). Development and Coastal Environment Change, Will Have A Meeting Point? Case Study of Coastal Zone of West Java Province, Indonesia. GeoJournal of Tourism and Geosites, 31(3), 1034-1042. https://doi.org/10.30892/gtg.31315-538

Rola, A.C., Jamias, S.B., \& Quizon, J.B. (2002). Do farmer field school graduates retain and share what they learn: an investigation in Iloilo, Philippines. Journal of International Agricultural and Extension Education, 9, 65-76. https://doi.org/10.5191/jiaee.2002.09108

Sakata, H., \& Prideaux, B. (2012). An alternative approach to community-based ecotourism: A bottom-up locally initiated non-monetized project in Papua New Guinea. Journal of Sustainable Tourism. https://doi.org/10.1080/09669582.2012.756493

Scheyvens, R. (2009). Pro-poor tourism: Is there value beyond the rhetoric? Tourism Recreation Research, 34, 191-196. https://doi.org/10.1080/ 02508281.2009 .11081590

Schmidttraub, G., Kroll, C., Teksoz, K., Duranddelacre, D., \& Sachs, J.D. (2017). National baselines for the sustainable development goals assessed in the SDG index and dashboards. Nature Geoscience, 10, 547-555. https://doi.org/doi:10.3390/su10030849

Shen, J.B, Cui, Z.L, Miao, Y.X., Mi, G.H., Zhang, H.Y., Fan, M.S., Zhang, C.C., Jiang, R.F., Zhang, W.F., Li, H.G., Chen, X.P., Li, X.L., \& Zhang, F.S. (2013). Transforming agriculture in china: from solely high yield to both high yield and high resource use efficiency. Global Food Security, 2, 1-8. https://doi.org/10.1016/S2095-3119(17)61774-X

Snapp, S., Kanyama-Phiri, G., Kamanga, B., Gilbert, R., \& Wellard, K. (2002). Farmer and researcher partnerships in Malawi: developing soil fertility technologies for the near-term and far-term. Experimental Agriculture, 38, 411-431. https://doi.org/10.1017/S0014479702000443

Vuillot, C., Coron, N., Calatayud, F., Sirami, C., Mathevet, R., \& Gibon, A. (2016). Ways of farming and ways of thinking: do 'farmers' mental models of the landscape relate to their land management practices? Ecology \& Society, 21 1-10. http://dx.doi.org/10.5751/ES-08281-210135

Whyte, W.H. (1980). The Social Life of Small Urban Spaces. The Conservation Foundation Washington, D.C.

Yuan, Z.W., Jiang, S., Sheng, H., Liu, X., Hua, H., \& Liu, X. (2018). Human perturbation of the global phosphorus cycle: changes and consequences. Environmental Science \& Technology, 52, 1-10. https://doi.org/10.1021/acs.est.7b03910

Zhang, F.S, Chen, X.P., Vitousek, P.M. (2013). Chinese agriculture: an experiment for the world. Nature, 497, 33-35. https://doi.org/10.1038/497033a

Zhang, F.S., Cui, Z.L., Fan, M.S., Zhang, W.F., Chen, X.P., \& Jiang, R.F. (2011). Integrated soil-crop system management: Reducing environmental risk while increasing crop productivity and improving China's nutrient use efficiency. Journal of Environmental Quality, 40, 1051-1057. https://doi.org/10.2134/jeq2010.0292

*** Parakansalak village monograph. (2019). Parakansalak sub-district. Parakansalak sub-district office. Sukabumi District. 